\section{Short Tandem Repeat (STR)}

\section{J. Arnemann}

Abteilung Molekulargenetik, Labor Dr. Wisplinghoff, Köln, Deutschland

Synonym(e) STR; Mikrosatelliten

Englischer Begriff short tandem repeat; STR

Definition Mikrosatelliten oder Short Tandem Repeats (STR) definieren kurze, sich hintereinander wiederholende Basenpaarabfolgen in nicht kodierenden Abschnitten der DNA, die aufgrund einer oft variablen Anzahl zur individuellen Typisierung menschlicher DNA eingesetzt werden.

Beschreibung In den nicht kodierenden Abschnitten der genomischen DNA finden sich Abschnitte mit kurzen, sich wiederholenden konstanten Basenpaarabfolgen, wie z. B. $(\mathrm{CA})_{\mathrm{n}}$ oder $(\mathrm{GATA})_{\mathrm{n}}$. Aufgrund der zahlreichen Wiederholungen in der Einzelanordnung, aber auch in der Verteilung im Genom werden diese Abschnitte als repetitive Elemente oder auch Mikrosatelliten bezeichnet. Der Begriff Mikrosatellit ist darauf zurückzuführen, dass in der früher durchgeführten DNA-Gradientenzentrifugation diese repetitiven Sequenzen oftmals als eigenständiger, kleiner Satellit dargestellt werden konnten.

In der aktuellen Diagnostik werden STR durch PCR mit Primern aus den flankierenden DNA-Sequenzen amplifiziert und die Produkte entweder gelelektrophoretisch oder meist fluoreszenzmarkiert mittels Kapillarelektrophorese aufgetrennt und dokumentiert. In der Vaterschaftsdiagnostik, aber auch in der Forensik werden speziell festgelegte STR als Basis des DNA-Fingerprints eingesetzt, wobei die ermittelten Fragmentgrößen in Datenbanken, z. B. des Bundeskriminalamtes, abgespeichert werden und weltweit aufgrund der angepassten Laborstandards auch mit den Mustern anderer Individuen abgeglichen werden können.

\section{Literatur}

Fregeau CL, Fourney RM (1993) DNA typing with fluorescently tagged short tandem repeats: a sensitive and accurate approach to human identification. BioTechniques 15:100-119 